\title{
Receptor Binding and Effects of Insulin and NSILA-S on Glucose Transport and Metabolism in Adipocytes from Hypophysectomized Rats
}

\author{
E. Schoenle, J. Zapf, and E. R. Froesch \\ Metabolic Unit, Department of Medicine, University Hospital Zurich, Switzerland
}

\begin{abstract}
Summary. Isolated fat cells from normal and hypophysectomized rats have been compared with respect to: 1) binding of insulin and NSILA-S, and 2) effects of these two hormones on glucose transport and metabolism. Although both insulin and NSILA levels were decreased in the serum of hypophysectomized rats, insulin binding was decreased to about $63 \%$ of normal, whereas NSILA-S binding remained unchanged. Basal lipogenesis was similar in adipocytes of normal and hypophysectomized rats, but was not stimulated by either insulin or NSILA-S. Similarly, neither of the two hormones stimulated the net gas exchange of "intact" fat pads from hypophysectomized rats. In striking contrast to these findings, 3-O-methylglucose transport in unstimulated fat cells of hypophysectomized rats proceeded at a maximal rate which was not further enhanced by insulin or NSILA-S. These results suggest that the lack of one or several hormones of the pituitary causes one or several enzyme deficiencies responsible for the limited rate of lipogenesis, which otherwiese would proceed at a very rapid rate because of unrestrained glucose transport.
\end{abstract}

Key words: Insulin, NSILA-S, adipocytes, hypophysectomized rats, insulin-receptor, NSILA-S-receptor, glucose metabolism, glucose transport.

Insulin is an important factor regulating the number of insulin receptors in different types of cells. In adipocytes or liver membranes of hyperinsulinaemic obese hyperglycemic mice (1-5) and in adipocytes and/or monocytes of patients with maturity onset diabetes [6] or obesity $[7,8]$, both relatively hyperinsulinaemic, the number of insulin receptors is decreased. "Down"-regulation by insulin of the number of insulin receptors was also observed in vitro in IM 9 lymphocytes [9]. In fasted [10, 11] and gentically diabetic $[5,12]$ animals with clearly decreased serum insulin levels the number of insulin receptors on adipocytes and liver membranes was increased. Increased insulin binding was also demonstrated in fat cells [13] and liver membranes [5, 14] from streptozotocin-diabetic animals and in thymocytes of very young hypophysectomized rats [15].

In contrast, the binding of nonsuppressible insulinlike activity (NSILA-S) to adipocytes of streptozotocin-diabetic rats was decreased [13] despite low concentrations of serum NSILA.

In this study we have tried to answer the following questions:

1) Is the reciprocal relationship between the insulin level and the number of insulin receptors also valid for adipocytes of hypophysectomized rats?

2) Is there an upward regulation of NSILA-S receptors in hypophysectomized rats whose serum NSILA-S-concentrations are even lower than in diabetic rats?

3) Is glucose transport and glucose metabolism in fat cells of hypophysectomized (hypox) rats normal, and are the receptor data reflected in the response of the tissues to these hormones?

\section{Materials and Methods}

Hypophysectomized male Tif RAI (formerly Sprague Dawley) rats, weighing between 120 and $140 \mathrm{~g}$ were a gift from Dr. Maier and Mr. Meier, Ciba-Geigy AG, Basel, Switzerland. This weight was chosen for the purpose of comparison with earlier results obtained with another strain of rats $[13,16]$. Hypophysectomy was carried out three to five weeks before the experiments. Only rats which did not gain weight during that period were used. They were fed ad lib with NAFAG chow (no. 890, NAFAG, Gossau, Switzerland) consisting of $65 \%$ of cereals, $20 \%$ of protein and $5 \%$ fat. The rats were decapitated at about 9 a.m. Serum insulin was measured with a radioimmunoassay using rat insulin (Novo, 


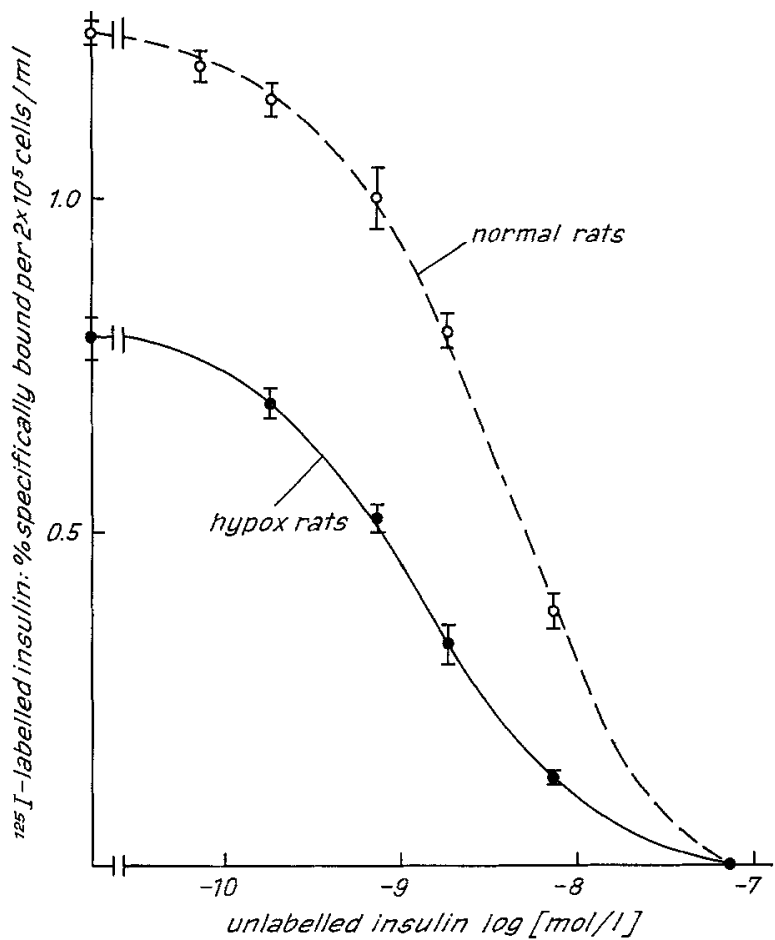

Fig. 1. Competitive inhibition of the binding of ${ }^{125} I$-labelled insulin by unlabelled insulin in fat cells of normal $(O)$ and hypophysectomized rats $(\bullet)$. Nonspecific binding of ${ }^{125} \mathrm{I}$-insulin (in presence of $7.5 \times 10^{-8} \mathrm{~mol} / 1$ of unlabelled insulin) varied between $10-15 \%$ of the total binding and was subtracted from all values. Incubation was carried out for $45 \mathrm{~min}$ at $37^{\circ} \mathrm{C}$. The brackets give the SEM of 5 to 8 experiments carried out in duplicate

Denmark) as standard, anti-porcine insulin serum (guinea pig) and ${ }^{125} \mathrm{I}$-labelled porcine insulin (CIS, Italy, specific radioactivity 100 $\mu \mathrm{Ci} / \mu \mathrm{g})$. Rat serum was preincubated for $12 \mathrm{~h}$ with antiporcine insulin serum at $4^{\circ} \mathrm{C}$. Then, ${ }^{125}$ I-labelled insulin was added for additional $6 \mathrm{~h}$. Bovine $\gamma$-globulin (Sigma, $2 \mathrm{mg} / \mathrm{ml}$ ) was added before precipitation with polyethylene-glycol (according to the prescription of the RIA-gnost insulin kit from Hoechst, Germany). Determination of blood glucose was carried out in a glucose-analyzer (Beckman). Whale insulin (identical amino acid sequence to pork insulin) $(24 \mathrm{U} / \mathrm{mg})$ and NSILA-S $(3.8 \mathrm{mU} / \mathrm{mg})$ was kindly provided by Drs. E. Rinderknecht and R. E. Humbel. The biological activity of NSILA-S was standardized in the rat fat pad assay with insulin as the reference [17]. The molar concentration of NSILA-S was calculated on the basis of a molecular weight of $7500[18,19]$ and of an activity of $\sim 300 \mathrm{mU} / \mathrm{mg}$ [20]. Human serum albumin (HSA) was supplied by the Swiss Red Cross, Bern. It was dialyzed extensively against three changes of distilled water and filtered by sterile filtration before use. Streptomycin $(5 \mathrm{mg} /$ $100 \mathrm{ml})$ and penicillin $\left(10^{6} \mathrm{IU} / 100 \mathrm{ml}\right)$ were added.

3-O-Methylglucose was from Sigma, U- ${ }^{14} \mathrm{C}-3-0$-methylglucose and $\mathrm{U}-^{14} \mathrm{C}$-glucose from Amersham, Radiochemical Centre. The iodination procedure for insulin and NSILA-S $(200 \mathrm{mU} / \mathrm{mg}$, about $65 \%$ pure) has been described previously [21].

\section{Experimental Procedures}

Fat cells were prepared according the method of Rodbell [22] using crude collagenase (Worthington, Biochemical Centre).

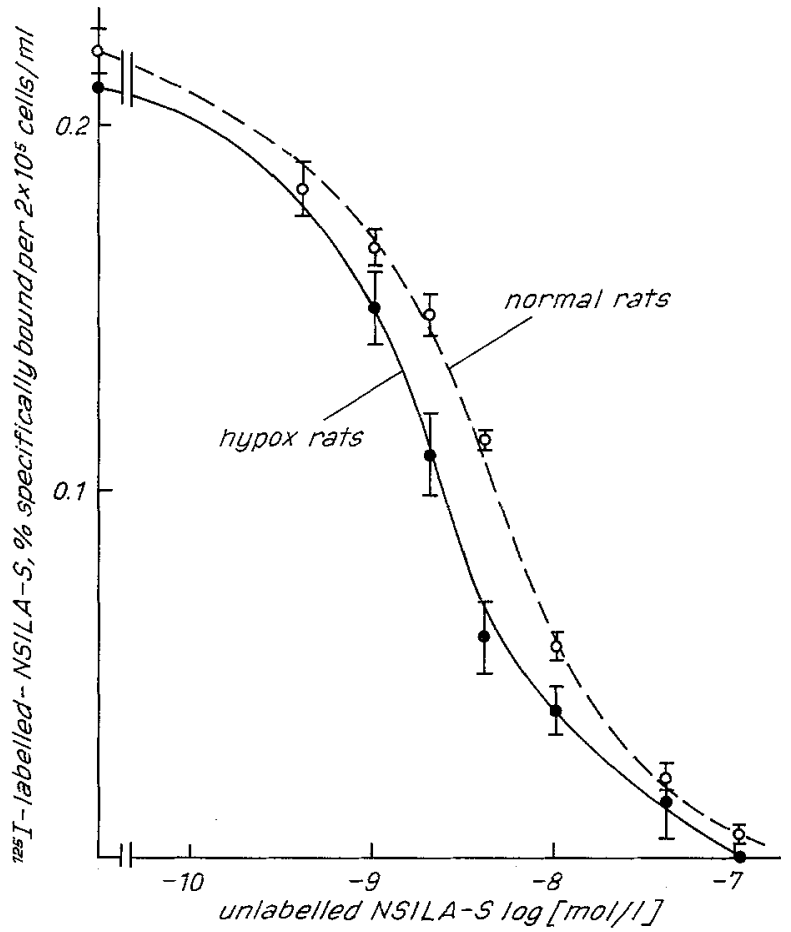

Fig. 2. Competitive inhibition of the binding of ${ }^{125}$ I-NSILA-S by unlabelled NSILA-S (specific activity $3.8 \mathrm{mU} / \mathrm{mg}$ ) in fat cells of normal $(O)$ and hypophysectomized rats $(\bullet)$. Incubation lasted for $45 \mathrm{~min}$ at $37^{\circ} \mathrm{C}$. Nonspecific binding (in presence of $2.0 \times$ $10^{-7} \mathrm{~mol} / 1$ of unlablled NSILA-S) varied between 20 and $35 \%$ of total binding and was subtracted. Brackets give the SEM of 4 to 8 incubations

Binding and metabolic studies were carried out in the same manner as described in a preceeding paper [13]. Fat cells $(2-4 \times$ $10^{5} / \mathrm{ml}$ ) were incubated for 45 minutes at $37^{\circ} \mathrm{C}$ in Krebs-Ringerbicarbonate buffer containing HSA $1 \mathrm{~g} / 100 \mathrm{ml}$ and glucose $1.1 \mathrm{mmol} / \mathrm{l}$. Specific binding of insulin and NSILA-S was measured as detailed in the legends to Figures 1 and 2. Glucose incorporation into total lipids was determined by the method of Gliemann et al. [23, 24].

Transport studies were performed as described earlier [13] with the following slight modifications: The fat cells prepared from fat pads of 8-10 rats were preincubated under gentle stirring for $45 \mathrm{~min}$ at $37^{\circ} \mathrm{C}$ in $3-4 \mathrm{ml}$ of Krebs-Ringer bicarbonate buffer containing $30 \mathrm{mmol} / \mathrm{l}$ of $\mathrm{U}^{-14} \mathrm{C}-3-0$-methylglucose $(\sim 20 \mu \mathrm{Ci})$. The cell suspension was then divided into 4 aliquots. The cells were separated from the buffer by centrifugation through an oil layer (dinonylphthalate, Merck) at $500 \mathrm{~g}$ and rapidly resuspended in $5 \mathrm{ml}$ of the same buffer containing cold 3-0-methylglucose $(30 \mathrm{mmol} / 1)$ alone (control), or, in addition, insulin, $(7.5 \times$ $10^{-10} \mathrm{~mol} / 1$ or $\left.7.5 \times 10^{-7} \mathrm{ml} / \mathrm{l}\right)$ or NSILA-S $\left(4.0 \times 10^{-8} \mathrm{ml} / 1\right)$. After different time intervals $300 \mu$ laliquots were pipetted into $400 \mu \mathrm{l}$ microtubes and centrifuged at high speed through a layer $(50 \mu 1)$ of dinonylphthalate $[13,23,25]$. The tops of the microtubes were cut off and counted in $5 \mathrm{ml}$ of Instagel (Packard) in a beta-counter (Tricarb, Packard). The radioactivity recovered in the cell layer after $10 \mathrm{~min}$. in the presence of $7.5 \times 10^{-7} \mathrm{~mol} / 1$ of insulin corresponds to the extracellular water space determined with ${ }^{3} \mathrm{H}$-insulin (not shown). It was subtracted from all values. The measured radioactivity was extrapolated to zero-time as described earlier [13]. 


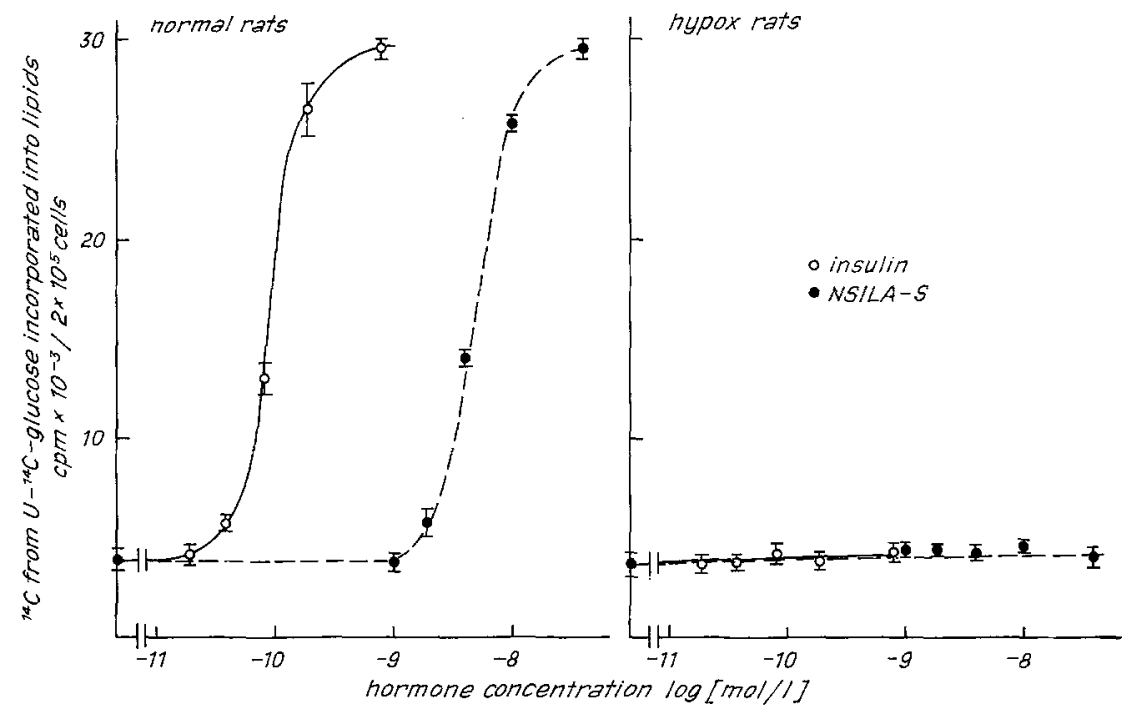

Fig. 3. Lipogenesis from $\mathrm{U}^{14} \mathrm{C}$-glucose in fat cells of normal and hypophysectomized rats stimulated by insulin (four experiments in triplicate) $(O)$ or NSILA-S (one experiment in triplicate) (•). Glucose concentration was $1.1 \mathrm{mmol} / 1$. Incubation was carried out at $37^{\circ} \mathrm{C}$ for $45 \mathrm{~min}$. The brackets give the SEM
Net gas exchange in whole adipose tissue was measured as described in detail earlier [17].

\section{Results}

\section{1) Binding Studies}

Figure 1 shows the competitive inhibition of the binding of ${ }^{125}$ I-labelled insulin by unlabelled insulin in fat cells of normal and hypophysectomized rats.

Specific binding of ${ }^{125} \mathrm{I}$-labelled insulin in fat cells of hypophysectomized rats was decreased to $63 \%$. Half-maximal displacement occurred at $3.2 \times$ $10^{-9} \mathrm{~mol} / 1$ in normal adipocytes and at $1.4 \times$ $10^{-9} \mathrm{~mol} / 1$ in fat cells of hypox rats.

Specific binding of ${ }^{125}$ I-labelled NSILA-S (Fig. 2) was the same for adipocytes of hypophysectomized and normal rats, $0.22 \%$ and $0.21 \%$ respectively. Half-maximal "displacement" by unlabelled NSILA$S$ was achieved at $2.1 \times 10^{-9} \mathrm{~mol} / 1$ in hypox and at $3.5 \times 10^{-9} \mathrm{~mol} / \mathrm{l}$ in normal fat cells.

${ }^{125}$ I-labelled NSILA-S was not displaced by unlabelled insulin. On the contrary, binding of labelled NSILA-S was increased in the presence of unlabelled insulin. As with adipocytes of streptozotocin-diabetic rats [13] this phenomenon was less pronounced in adipocytes of hypox $(+32 \%)$ than in adipocytes of normal rat $(+180 \%$ in the presence of unlabelled insulin, $7.5 \times 10^{-9} \mathrm{~mol} / 1$; not shown).

\section{2) Metabolic Studies}

The differences in the metabolic responses to both insulin and NSILA-S between fat cells of normal and hypophysectomized rats are considerable (Figure 3 ).
Table 1. Insulin and NSILA-S stimulated net gas exchange in whole adipose tissue of hypophysectomized rats. Experiments were carried out in duplicate, with normal adipose tissue as a control, as described in detail in [17]. The biological activity of NSILA-S was standardized in normal rat adipose tissue with insulin as the reference [17]

\begin{tabular}{lcc}
\hline & \multicolumn{2}{c}{ Net gas exchange $(\mu \mathrm{l} / \mathrm{g} \times \mathrm{h})$} \\
\cline { 2 - 3 } & Hypox rats & Normal rats \\
\hline Insulin: $\mathrm{mol} / \mathrm{l}$ & & \\
$0.75 \times 10^{-10}$ & $68 \pm 12$ & $63 \pm 5$ \\
$2.25 \times 10^{-10}$ & $158 \pm 16$ & $300 \pm 28$ \\
$6.75 \times 10^{-10}$ & $140 \pm 31$ & $623 \pm 31$ \\
$20.25 \times 10^{-10}$ & $150 \pm 45$ & $845 \pm 36$ \\
NSILA-S: mol/1 & & \\
$0.4 \times 10^{-8}$ & $86 \pm 3$ & \\
$0.8 \times 10^{-8}$ & $91 \pm 12$ & \\
$1.2 \times 10^{-8}$ & $106 \pm 21$ & \\
$3.2 \times 10^{-8}$ & $108 \pm 2$ & \\
\hline
\end{tabular}

In normal rats lipogenesis was stimulated by increasing concentrations of insulin (half-maximal at $\sim 8.5$ $\times 10^{-11} \mathrm{~mol} / \mathrm{l}$ ) and NSILA-S (half-maximal at $\sim 5.1$ $\left.\times 10^{-9} \mathrm{~mol} / \mathrm{l}\right)$. In fat cells of hypophysectomized rats (Figure 3) neither insulin nor NSILA-S stimulated lipogenesis to a significant extent.

The basal rate of ${ }^{14} \mathrm{C}$-incorporation into total lipids was the same in fat cells of normal and hypox rats.

In a control assay, insulin stimulated net gas exchange in intact adipose tissue of hypox rats only to a very small extent compared to adipose tissue of normal rats (Table 1 ). 


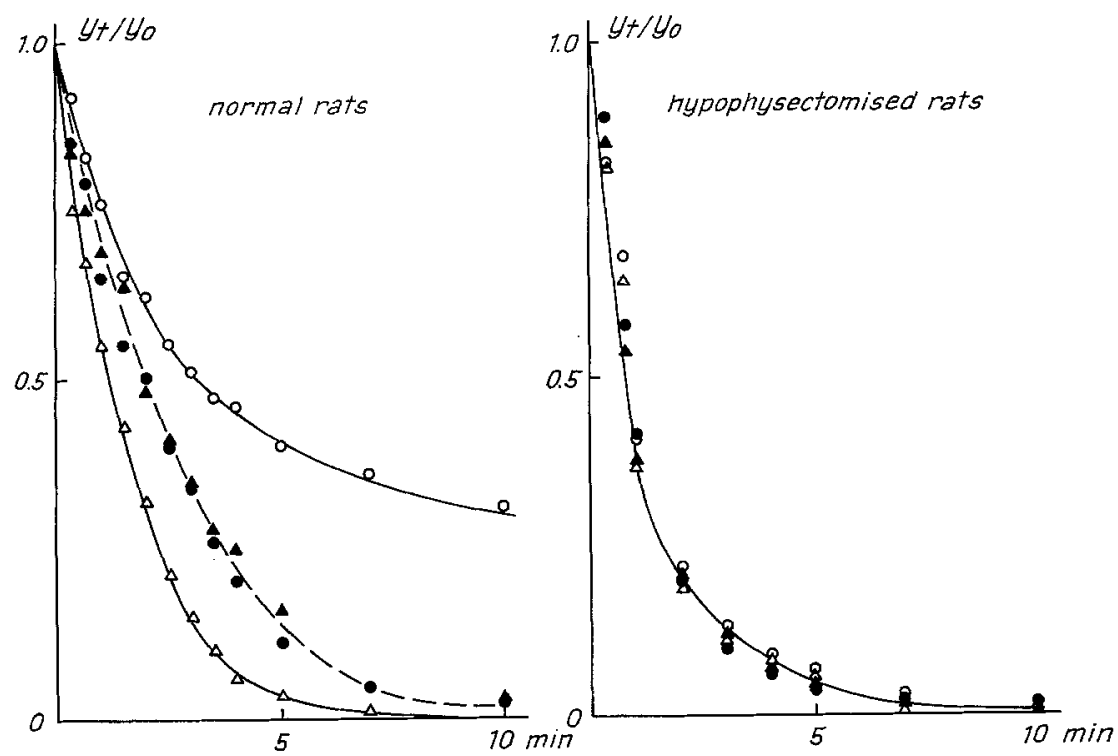

Fig. 4. Efflux of 3-0-methyl-U- ${ }^{14} \mathrm{C}-$ glucose from fat cells of normal and hypophysectomized rats. $O-O$ basal efflux; $\triangle \longrightarrow \triangle$ efflux in the presence of $7.5 \times 10^{-7} \mathrm{~mol} / \mathrm{l}$ of insulin added at zero time; efflux in the presence of insulin $\left(7.5 \times 10^{-10} \mathrm{~mol} / \mathrm{l}\right) \boldsymbol{\Delta}-\boldsymbol{\Delta}$ or NSILA-S $\longrightarrow,\left(4.0 \times 10^{-8} \mathrm{~mol} / \mathrm{l}\right)$ added at zero time. As described in the experimental procedure the value in the presence of $7.5 \times 10^{-7} \mathrm{~mol} / 1$ of insulin obtained after $10 \mathrm{~min}$ (between 10 and $20 \%$ of the total counts) was subtracted from all values. Each point gives the mean of 3 to 6 incubations. For the sake of clarity the SEM's are not shown. They ranged from 0.01 to 0.04

\section{3) Transport Studies}

In Figure 4 the time curves of the efflux of 3-0methylglucose from adipocytes of normal and hypophysectomized rats are shown. In normal adipocytes the half-life of basal efflux was $\sim 180 \mathrm{sec}$, that of maximally stimulated efflux in the presence of 7.5 $\times 10^{-7} \mathrm{~mol} / 1$ of insulin $\sim 75 \mathrm{sec} .7 .5 \times 10^{-10} \mathrm{~mol} / 1$ of insulin or $4.0 \times 10^{-8} \mathrm{~mol} / 1$ of NSILA-S caused a similar enhancement of 3-0-methylglucose efflux.

Glucose transport in adipocytes of hypophysectomized rats appeared to proceed at a maximal rate already in the basal state. The time curve of the efflux of 3-0-methylglucose in the absence of insulin or NSILA-S was the same as that in the presence of 7.5 $\times 10^{-7} \mathrm{~mol} / 1$ of insulin in normal adipocytes. It could not be further stimulated by insulin $(7.5 \times$ $\left.10^{-10} \mathrm{~mol} / \mathrm{l}\right)$ or NSILA-S $\left(4.0 \times 10^{-8} \mathrm{~mol} / \mathrm{l}\right)$ nor by a maximal dose of insulin $\left(7.5 \times 10^{-7} \mathrm{~mol} / 1\right)$ (Fig. 4).

\section{4) Serum Insulin and NSILA-S Levels}

Serum insulin levels in hypox rats were $(1.5 \pm 0.1) \times$ $10^{-10} \mathrm{~mol} / 1$ compared to $(3.6 \pm 0.3) \times 10^{-10} \mathrm{~mol} / 1$ in normal rats $(\mathrm{n}=8)$, whereas the plasma glucose concentrations were in the same range $(7.4 \pm 0.4$ for hypox vs. $7.1 \pm 0.3 \mathrm{mmol} / 1$ for normal rats).
The serum NSILA-S levels were $(2.4 \pm 0.8) \times$ $10^{-9} \mathrm{~mol} / \mathrm{l}$ in hypophysectomized compared to $(51.6$ $\pm 2.4) \times 10^{-9} \mathrm{~mol} / 1$ in normal rats $(\mathrm{n}=6)$ [26]

\section{Discussion}

The results of the present binding studies are in agreement with earlier results obtained in a different strain of rats (Zbz-Cara) [13]: Although specific binding of ${ }^{125}$ I-labelled NSILA-S to normal adipocytes is somewhat lower than reported previously, half-maximal displacement by unlabelled NSILA-S is similar as is specific binding of ${ }^{125} \mathrm{I}$-labelled insulin and half-maximal displacement by unlabelled insulin.

At normal blood glucose concentrations the plasma insulin levels are decreased to about $40 \%$ of normal in hypophysectomized rats. Nevertheless, we do not find an increase but rather a decrease in insulin binding to isolated fat cells (Fig. 1). This finding is in contrast to the increased insulin binding in thymocytes of hypox rats observed by Goldfine [15] and thus to the current concept that there is a reciprocal relationship between serum insulin levels and the number of insulin binding sites (5-15). Furthermore, NSILA-S binding is unchanged (Fig. 2) in fat cells of hypox rats despite decreased circulating NSILA-S levels.

Lipogenesis in adipocytes of hypophysectomized 
rats could not be stimulated by insulin or NSILA-S (Fig. 3). Insensitivity to insulin of adipocytes from hypox rats has also been reported by Eastman and Goodman [27]. We can rule out decreased glucose transport as the cause since basal 3-0-methylglucose efflux in adipocytes of hypox rats is already very fast and cannot be further stimulated by hormones (Fig. 4). Thus, the adipocyte of the hypox rat presents an interesting peculiarity: glucose penetration into the cell no longer seems to be the rate-limiting step of glucose metabolism, and insulin does not appear to play a major role in modulating the availability of glucose to the cell.

In good agreement with the lack of an effect of insulin and NSILA-S on glucose transport is the lack of any detectable effects on glucose metabolism. Since transport is not restricted, the rate-limiting step in glucose metabolism must lie at a more distant level and may involve pyruvate dehydrogenase or fatty acid synthetase [28]. Preliminary results obtained in hypox rats substituted with T3, ACTH and growth hormone, alone and in combination, point to interesting regulatory mechanisms of these hormones in glucose metabolism: Growth hormone treatment restores basal glucose transport and its responsiveness to insulin to normal, whereas treatment with ACTH and T3, at least partly, restores the ability of the fat cell for glucose incorporation into total lipids (Schoenle et al., in preparation).

The possibility that the lack of response of fat cells of hypophysectomized rats to insulin and NSILA-S may be due to cell damage is unlikely: 1) NSILA-S binding is the same in normal fat cells as in fat cells of hypox rats, and the reduction of insulin binding is less drastic than one would expect from the complete lack of any metabolic response to insulin 2) Basal lipogenesis is the same in both conditions. 3) Although very rapid and not responsive to insulin, the basal 3-0-methylglucose efflux follows first order kinetics as does the maximally stimulated efflux in normal fat cells 4) Furthermore, 3-0-methyl-glucose efflux is inhibited by phlorizin (Schoenle et al., in preparation). In agreement with the reported findings in cells, glucose utilization and net gas exchange are barely enhanced by insulin or NSILA-S in intact adipose tissue of hypox rats.

Insulin may regulate the number of its tissue binding sites reciprocally under certain circumstances (1-15). However, our studies show, that this concept cannot be generalized e.g. for hypophysectomized rats: insulin binding to adipocytes is decreased in spite of low serum insulin levels. With respect to NSILA-S binding no consistent correlation with NSILA-S levels in serum is found: Both hypox and diabetic rats have decreased serum NSILA levels.
However, NSILA-S binding is unchanged in fat cells of hypox rats, whereas it is decreased in fat cells of diabetic rats [13].

Acknowledgements. This work was supported by grant No. 3.595. -0.75 from the Swiss National Science Foundation.

We thank Dr. R. Maier and Mr. Meier, Ciba-Geigy AG, Basel for their kind supply of the hypophysectomized rats and Ms. G. Jagars and I. Sand for carrying out the fat pad assay.

\section{References}

1. Kahn, C. R., Neville, D. M., Jr., Gorden, P., Freychet, P., Roth, J.: Insulin receptor defect in insulin resistance: Studies in the obese hyperglycemic mouse. Biochem. Biophys. Res. Commun. 48, 135-142 (1972)

2. Freychet, P., Laudat, M. H., Laudat, P., Rosselin, G., Kahn, C. R., Gorden, P., Roth, J.: Impairment of insulin binding to the fat cell plasma membrane in the obese hyperglycemic mouse. FEBS Lett. 25, 339-342 (1972)

3. Freychet, P.: Interactions of polypeptide hormones with cell membrane specific receptors: Studies with insulin and glucagon: Minkowski Award Lecture 1975. Diabetologia 12, 83-100 (1976)

4. Soll, A. M., Kahn, C. R., Neville, D. M., Roth, J.: Insulin receptor deficiency in genetic and aquired obesity. J. Clin. Invest. 56, 769-780 (1975)

5. Renner, R., von Funcke, H. J., Hepp, K. D.: The number of insulin receptors as a function of insulin levels in blood. Diabetologia 12, 416 (Abstr.) (1976)

6. Olefsky, J. M., Reaven, G. M.: Insulin binding in diabetes: relationship with plasma insulin levels and insulin sensitivity. Diabetes 26, 680-688 (1977)

7. Olefsky, J.M.: Decreased insulin binding to adipocytes and circulating monocytes from obese subjects. J. Clin. Invest. 57, 1165-1172 (1976)

8. Bar, R. S., Gorden, P., Roth, J., Kahn, C. R., De Meyts, P.: Fluctuations in the affinity and concentration of insulin receptors on circulating monocytes of obese patients: effects of starvation, refeeding and dieting. J. Clin. Invest. 58, 1123-1135 (1976)

9. Gavin, J. R. III., Roth, J., Neville, D. M., Jr., De Meyts, P., Buell, D. N.: Insulin-dependent regulation of insulin receptor concentration: A direct demonstration in cell culture. Proc. Natl. Acad. Sci. USA 71, 84-88 (1974)

10. Olefsky, J.M.: Effects of fasting on insulin binding, glucose transport and glucose oxidation in isolated rat adipocytes: relationship between insulin receptors and insulin action. J. Clin. Invest. 58, 1450-1460 (1976)

11. Kasuga, M., Akamuna, Y., Iwamoto, Y., Kosaka, K.: Effects of fasting and refeeding on insulin receptors and glucose metabolism in rat adipocytes. Endocrinology 100, 1384-1390 (1977)

12. Hepp, K. D., Langley, J., Von Funcke, M. J., Renner, R., Kemmler, W.: Increased insulin binding capacity of liver membranes from diabetic chinese hamsters. Nature 258, 154 (1975)

13. Schoenle, E., Zapf, J., Froesch, E. R.: Effects of insulin and NSILA on adipocytes of normal and diabetic rats: Receptor binding, glucose transport and glucose metabolism. Diabetologia 13, 243-249 (1977)

14. Davidson, M. B., Kaplan, S. A.: Increased insulin binding by hepatic plasma membranes from diabetic rats. Normalization by insulin therapy. J. Clin. Invest. 59, 22-30 (1977) 
15. Goldfine, I. D.: Binding of insulin to thymocytes from suckling and hypophysectomized rats: Evidence for two mechanisms regulating insulin sensitivity. Endocrinology 97, 948-954 (1975)

16. Schoenle, E., Zapf, J., Froesch, E. R.: Binding of nonsuppressible insulin-like activity (NSILA) to isolated fat cells: evidence for two separate membrane acceptor sites. FEBS Lett. 67, 175-179 (1976)

17. Froesch, E. R., Bürgi, H., Ramseier, E. B., Bally, P., Labhart, A.: Antibody-suppressible and nonsuppressible insulin-like activities in human serum and their physiologic significance. An insulin assay with adipose tissue of increased precision and specificity. J. Clin. Invest. 42, 1816-1834 (1963)

18. Rinderknecht, E., Humbel, R. E.: Amino-terminal sequences of two polypeptides from human serum with nonsuppressible insulin-like and cell growth promoting activities: Evidence for structural homology with insulin B chain. Proc. Natl. Acad. Sci. USA 73, 4379-4381 (1976)

19. Rinderknecht, E., Humbel, R. E.: The amino acid sequence of human insulin-like growth factor I and its structural homology with proinsulin. J. Biol. Chem. 253, 2769-2776 (1978)

20. Zapf, J., Schoenle, E., Froesch, E. R.: NSILA I and II: Some biological actions and receptor binding characteristics of two purified constituents of nonsuppressible insulin-like activity of human serum. Eur. J. Biochem. 87, 285-296 (1978)

21. Zapf, J., Mäder, M., Waldvogel, M., Schalch, D. S., Froesch, E. R.: Specific binding of nonsuppressible insulin-like activity to chicken embryo fibroblasts and to a solubilized fibroblast receptor. Arch. Biochem. Biophys. 168, 630-637 (1975)
22. Rodbell, M.: Metabolism of isolated fat cells. 1. Effect of hormones on glucose metabolism and lipolysis. J. Biol. Chem. 239, 375-380 (1964)

23. Gammeltoft, S., Gliemann, J.: Binding and degradation of ${ }^{125} \mathrm{I}$-insulin by isolated rat fat cells. Biochim. Biophys. Acta 320, 16-32 (1973)

24. Gliemann, J., Gammeltoft, S., Vinten, J.: Time course of insulin receptor binding and insulin induced lipogenesis in isolated rat fat cells. J. Biol. Chem. 250, 3368-3374 (1975)

25. Vinten, J., Gliemann, J., Osterlind, K.: Exchange of 3-0methylglucose in isolated fat cells: Concentration dependence and effect of insulin. J. Biol. Chem. 251, 794-800 (1976)

26. Kaufmann, U., Zapf, J., Froesch, E. R.: Growth hormone dependence of NSILA and of NSILA-carrier protein in rats. Acta Endocrinol. (Kbh.) 87, 716-727 (1978)

27. Eastman, R. C., Goodman, H. M.: Insensitivity of adipocytes of hypophysectomized rats to growth hormone and insulin. Proc. Soc. Exp. Biol. Med. 137, 168-174 (1971)

28. Czech, M. P., Richardson, D. K., Smith, C. J.: Biochemical basis of fat cell insulin resistance in obese rodents and man. Metabolism 26, 1057-1078 (1977)

Received: April 24, 1978, and in revised form: August 15, 1978

Dr. E. Schoenle

Metabolic Unit

Department of Medicine

University Hospital

CH-8091 Zürich, Switzerland 